\title{
Francisco de Vitoria on the Right to Free Trade and Justice
}

\author{
Alejo José G. Sison \\ Dulce M. Redín \\ University of Navarra
}

\begin{abstract}
In 1538-39 Francisco de Vitoria delivered two relections: De Indis and De iure belli. This article distills from these writings the topic of free trade as a "human right" in accordance with ius gentium or the "law of peoples." The right to free trade is rooted in a more fundamental right to communication and association. The rights to travel, to dwell, and to migrate precede the right to trade, which is also closely connected to the rights to preach, to protect converts, and to constitute Christian princes. This has significant repercussions on the field of business ethics: the right to free trade is ultimately founded directly on natural law and indirectly on divine law; trade is not independent of ethics; and trade is presented as an opportunity to develop the virtues of justice and friendship, among other repercussions. Vitoria is portrayed as a defender of private initiative and free markets.
\end{abstract}

Key Words: Francisco de Vitoria, ius gentium, ius commercium, free trade, business ethics

\begin{abstract}
A lthough Adam Smith (1723-90) is universally credited as the founder of modern economic science, Schumpeter (1954) claims that this title rightfully belongs instead to a group of fifteenth-century Late Scholastics pertaining to the School of Salamanca. This group constituted an epistemic community and a community of practice rooted in the Catholic tradition, uniquely combining respect for authority and prudential reasoning to provide normative guidance on practical issues (Duve, 2020) and early writings in business ethics (Muñoz de Juana, 2001; Wren, 2000). Although trained originally as philosophers, theologians, and canon lawyers, they were nevertheless able to lay down the theoretical groundwork for understanding how the economy and markets function, anticipating modern conceptions of value, price, the monetary system, banking, taxation, and government regulation, among other ideas (Grice-Hutchinson, 1952, 1975). More importantly for business ethics, they brought to bear universal, rational principles from a largely Thomistic interpretation of justice and natural law on moral judgments over commercial transactions. Most scholarly publications in business ethics focus, however, on the followers of the School of Salamanca, such as Martín de Azpilcueta, Diego de Covarrubias, Luis de Molina, or Tomás de Mercado, with precious little said about its founder, Francisco de Vitoria (Alves \& Moreira, 2013; Melé, 1999). This article addresses this gap, particularly in
\end{abstract}


reference to the right to commerce or free trade enshrined in ius gentium (law of the peoples) and the virtue of justice.

We begin by providing the necessary historical context of Vitoria's work. As theology professor at the University of Salamanca, Vitoria was called upon to help elucidate the lawfulness of Spain's presence in the Americas. His systematic study bore two major relections, De Indis (On the American Indians) and De iure belli (On the law of war), delivered between December 1538 and June 1539 (Urdánoz, 1960). Let us turn briefly to each.

Vitoria's line of reasoning in De Indis goes through four stages. First, he observes that before the coming of the Spaniards, the Amerindians already exercised dominion over public and private matters (quaestio 1) ${ }^{1}$ (Vitoria, 1991: 239-51). There was order in social life, with marriage and family institutions, cities, magistrates, laws, industries, commerce, and religion, all of which prove a rational human nature. As rational beings, they could not be considered slaves by intrinsic constitution, nor could they be dispossessed of property without cause. Amerindians possessed rights of dominion and ownership by divine or natural law despite not being Christian believers.

Second, Vitoria invalidates the titles of conquest then commonly invoked (quaestio 2) (Vitoria, 1991: 251-77). He rejects Emperor Charles V's claims to "supremacy" (praelatio) as without basis on divine, natural, or human law. Similarly, he denies the pope's authority over the New World and its inhabitants, who were "infidels" or "unbelievers." Equally dismissed were titles based on the "right to discovery" and the law ferae bestiae (by which all things unoccupied or deserted become property of the first finder or occupier). Undeniably, the Amerindians inhabited the New World long before the Europeans arrived.

Third, Vitoria examines the legitimacy of other titles (quaestio 3) (Vitoria, 1991: 277-91) founded on natural law and ius gentium. Foremost is the "right of communication and human society" (ius communicationis et societatis humanae), a direct consequence of the social nature of human beings. Because of their common humanity, people have the "right to travel and dwell," the "right to migrate," and the "right to trade," thus obtaining whatever is necessary for subsistence. A next set of titles includes the "right to spread the Christian religion" (Vitoria, 1991: 284-86), the "right to protect converts" (Vitoria, 1991: 286), and the "right to constitute a Christian prince" (Vitoria, 1991: 287). Finally are the "right to defend the innocent against tyranny," against the abominable practice of human sacrifice (Vitoria, 1991: 287-88), and the "right to defend allies and friends," based on the relationship between Spaniards and Tlaxcaltecs against their common enemy, the Mexicans (Vitoria, 1991: 289-90).

Vitoria concludes, quite shockingly, that having been deprived of these rights, Spaniards were justified in waging war against American natives and occupying their lands (Vitoria, 1991: 291-92).

\footnotetext{
${ }^{1}$ In the Middle Ages, philosophical treatises such as those of Vitoria were structured into questions (quaestiones) and articles.
} 
In the second relection, De iure belli (On the law of war), Vitoria ([1539] 1981) lays down the conditions, rules, and limits for a just war (Vitoria, 1991: 293-327). He asks whether it would be lawful for Christians to wage war and responds that it is under natural law, both offensively (only princes) and defensively (even private citizens), to defend or reclaim property, as vengeance for injury or as a deterrent for injustice, and ultimately to achieve peace and security for the commonwealth. Vitoria explicitly rules out differences in religion, expansion of empires, and personal glory as valid grounds for war.

The purpose of this article is not to judge the Spanish conquest of the Americas or the inextricable issue of the defense of the dignity of American natives in Vitoria's writings. Rather, it is to disembed from the two relections free trade as a "human right" in accordance with ius gentium. This has significant repercussions on the moral status of parties to trade, their purposes or intentions, and the manner in which they conduct business, framed within the context of justice, the social virtue par excellence. These inferences signal a departure from the widespread impersonal, merely transactional or mechanistic view of commerce (Dierksmeier, 2019a), rendering it indifferent to human perfection and flourishing. Such is the importance of free trade that its denial constitutes a just cause for war. For Vitoria, the goal of war is peace; but there is no peace without security, which in turn requires justice and respect for the dignity and rights of human beings. Free and just trade is necessary for human flourishing. And when these conditions fail, his teachings contain provisions to ensure that war reestablishes peace and security by righting injustices (restorative justice) (Vitoria, 1991: 298).

We carry out our research in four steps. First, we offer an account of the origin, premises, and place of ius gentium within the body of laws. Second, we discuss the right to free trade in relation to other rights in ius gentium, such as the right to communicate and the right to travel and dwell, together with their implications. Third, we examine the relevance of these rights for business ethics: trade is subject to moral principles; free trade contributes to human flourishing and moral perfection through justice and friendship; states have a duty to protect and guarantee free trade as well as the free movement of peoples in travel, tourism, and migration. In the closing section, we identify areas for further research, such as the relevance of Vitoria's other writings for business ethics and the suggestion for an alternative, pre-Enlightenment theory of human rights.

\section{THE ORIGIN AND PREMISES OF IUS GENTIUM WITHIN THE BODY OF LAW}

A few clarifications are in order regarding ius gentium (law of peoples) in relation to natural law and positive or civil law, on one hand, and international law, on the other.

Ius gentium refers to laws based on natural justice that govern relationships among human beings as "peoples," regardless of citizenship in states. Its specific role is to govern interactions among "strangers," for instance, between Amerindians and Europeans who meet each other for the first time. Vitoria adopts Gaius's (1925) definition in Roman law (Fassó, 1982), such that ius gentium becomes the law 
natural reason establishes among all peoples, a common law for humankind (Truyol y Serra, 1977).

Although the Stoics were perhaps the first to speak of a universal human race characterized by reason, Christianity radically changed the belief by adding that all human beings are made in the "image and likeness of God" (Sison, Ferrero, \& Guitián, 2016). Vitoria belongs to this Christian tradition.

For Vitoria, despite cultural differences, Amerindians and Europeans belong to the same "universal community" or "commonwealth" (orbs) or "family of peoples" (gentium), subject to the same law (ius) or standard of justice. Rights conferred by ius gentium are not diminished by sin or heresy, such that Native Americans can claim to possess them fully.

Representing rudimentary political communities, "peoples" (gentes) are integrated within the commonwealth, where the universal temporal common good resides (Fernández Ruiz-Gálvez, 2017; Truyol y Serra, 1977). The orbs brings together all human beings and nations (communitas communitatum) united by natural bonds (Fernández Ruiz-Gálvez, 2017). Each "people" (gens) is sovereign, independent from external interferences and capable of self-government. The ruler of each gens is subject to divine law, natural law (a participation in the former), ius gentium, and the civil laws of the polity. Each gens is also juridically equal to any other, possessing the same rights and responsibilities in the orbs (Araujo, 2012).

The "whole commonwealth" (totus orbs) is not a superstate like the Holy Roman Empire or a Stoic civitas maxima (great city); it represents a "family of peoples." Vitoria imagines the entire human race forming a community (Barcia Trelles, 1928; Urdánoz, 1967). The orbs is neither a community of masters and subordinates, as in an empire, nor merely an instrument of contractual coordination between equal subjects; it is an interdependent system (Gascón y Marín, 1932; Scott, 1934). Subjects are not just independent individuals pursuing their own interests; their interests should be subordinated to the common good of the orbs.

Surprisingly for contemporary scholars, Vitoria considers ius gentium as a given, seeing no need to justify its existence. Instead, he turns to a long tradition of Greek, Latin, and medieval scholars (Salas, 2012). Gaius (1925) contrasts ius gentium to ius civile (civil law), the rules of particular states. Isidore of Seville (1983) differentiates laws according to origin: divine law is based on nature (and ultimately on God, its creator), human law on custom; ius gentium, like natural law, is valid for all peoples. Aquinas (2006), in the Summa Theologiae (hereinafter S Th), distinguishes between natural law (ius naturale) and positive law (ius positivum): ius gentium belongs to the former, as it is universal in scope and dependent on a natural instinct rather than a legislative act. From the foregoing, Vitoria takes the natural origin and universality of ius gentium.

It is beyond the scope or intent of this essay to explain the origin, justification, and history of natural law (Tierney, 1997). We simply wish to show the connections among natural law, ius gentium, and positive law (Salas, 2012). Following Aquinas (2006), by law, we understand "an ordinance of reason promulgated by competent authority for the sake of common good" ( $S$ Th I-II, q. 90, a. 4). Law is a rational 
imperative (command or prohibition) enacted by the community's authorities for the common good.

How does natural law differ from positive law? Positive law is explicit, derived, contingent, and "posited"; natural law is implicit, original, permanent, and "given." Positive law must be respectful of natural law, rather than simply expressing preferences of rulers or peoples. The difference between ius gentium and natural law, on one hand, and between ius gentium and positive law, on the other, however, is an old chestnut. Vitoria indicates that ius gentium derives from, but is not the same as, natural law (Vitoria, [1535] 2001: 23). Ius gentium is developed by human reason on the basis of natural law in relation to social organization. Its function is to protect what is characteristically human within cultural diversity (Sarmiento, 2009; Viola, 2004). It originates from a voluntary pact (Vitoria, [1535] 2001: 24) that entails objectivity and universality (Menéndez Reigada, 1931-32), generating true obligations. To act against ius gentium is illicit, implying injustice and inequality (Vitoria, [1535] 2001: 28). Whereas natural law contains what is just and necessary by nature without depending on the human will, ius gentium refers to what is just in reference to another human being. For example, peace and concord are demands of natural law, whereas the distribution of property, which leads to peace and concord, is a requirement of ius gentium. Vitoria considers dispositions that do not necessarily, absolutely, immediately, and clearly derive from natural law, needing instead (near-) universal consensus elements of ius gentium. Unlike natural law, ius gentium depends on universal agreement. However, because natural law cannot be properly observed without ius gentium, there is mutual dependence between the two.

Vitoria leaves room for nuance regarding universal consensus on ius gentium. For example, in matters that directly and immediately affect the common good of the $o r b s$, such as rights over the sea, a majority consensus is enough (Urdánoz, 1960). Dependent on practical reason, ius gentium may fail in deriving principles from natural law. This allows ius gentium to evolve, for instance, in the treatment of prisoners of war, who went from being executed to becoming slaves (Vitoria, [1539] 1981). Ius gentium is binding because it derives from natural law and is established by the authority of the orbs for the universal common good. Natural law gives ius gentium authority and validity, while epistemological consensus lends it legitimacy.

Ius gentium may be considered a precedent of international law. There are essential differences, nonetheless. The main difference refers to the statist character of modern international law, which recognizes only states as subjects. Beginning in the modern era, the idea of belonging to a common orbs is progressively replaced by citizenship in a state (Cruz Prados, 1991). State citizenship now precedes any other social condition. International law does not acknowledge the rights and responsibilities of nonstate communities or individual persons. Individual persons are only recognized as citizens of states; they have no rights in international law as individuals.

Because of their nature — and not any artificial social contract - all human beings, as individuals or as citizens of states, constitute the orbs. Ius gentium, an extension of natural law, promulgated by virtual consensus, is the law of the orbs. In ius gentium, 
all political communities are sovereign and equal, thus laying the foundations for international law.

\section{THE RIGHT TO FREE TRADE IN RELATION TO OTHER RIGHTS IN IUS GENTIUM}

Although Vitoria was particularly concerned about the effects of the "discovery" of the Americas on Spanish commerce and finances, he was even more preoccupied with its impact on the welfare of Amerindians and on the morals of his countrymen, including his own conscience. Vitoria writes in a letter addressed to his superior, Miguel de Arcos, about the massacre perpetrated by Pizarro and the assassination of the Inca Atahualpa: "As for the case of Peru, I must tell you, after a lifetime of studies and long experience, that no business shocks or embarrasses me more than the corrupt profits and affairs of the Indies. Their very mention freezes the blood in my veins. Yet I work as best I can, so that if they make off with the assets, at least I suffer no loss of that other asset, a clear conscience" (Vitoria, 1991: 331).

Since the right to free trade forms part of ius gentium, it is a matter of justice and germane to morals, human perfection, and flourishing. How does free trade connect with the other rights, whose denial justifies war?

The "right to communication and human society" is the first just title of conquest. The rights "to travel and dwell," "to migrate," and "to trade" follow from it. These are not privileges for a few but opportunities that could be exercised by all. As rights, they ought to be acknowledged, respected, and protected. For instance, communication and association would not be possible with other human beings further afield, without the rights to travel and dwell or to migrate. Often, travel is motivated by or results in trade, the mutually beneficial exchange of goods and services. Trade remedies local scarcities and makes resources available to all. These rights are meant to come together and should not be separated without good reason. Vitoria shows the incongruence of championing free trade and markets without respecting rights to travel, dwell, and migrate, for example. This stance seems to value things more than people and fails to see that trade realizes its full potential only when individuals get to know each other better, through a spiral of trustful relationships.

The right to trade states that "Spaniards may lawfully trade among the barbarians, so long as they do no harm to their homeland... They may import the commodities which they lack, and export the gold, silver, or other things which they have in abundance; and their princes cannot prevent the subjects from trading with the Spaniards, nor can the princes of Spain prohibit commerce with the barbarians" (Vitoria, 1991: 279). Vitoria insists on reciprocity: "Do as you would be done by.... It is certain that the barbarians can no more prohibit Spaniards from carrying on trade with them, than Christians can prohibit other Christians from doing the same" (Vitoria, 1991: 280).

Trade is not limited to precious metals but includes whatever some individuals and communities lack and others possess in abundance; rulers cannot prevent people from engaging in this activity without good reason. Infringement on free trade by civil authorities without just cause, through mercantilist and protectionist 
policies, for instance, is contrary to ius gentium. At the same time, Vitoria recognizes the right of the Spanish Crown to levy taxes for having discovered the sea route and protecting merchants, that is, for facilitating international trade. Being Amerindian or Spaniard, Christian or non-Christian, should not be a hindrance to trade. If Spaniards had commerce with other Christian kingdoms, they should be able to do the same with Amerindians, and vice versa. Mutually beneficial trade can promote brotherly love, toward which all peoples are enjoined by natural and divine precept.

Thus Vitoria proclaims freedom of international trade as a natural right, identifying three features: first, trade must be mutually beneficial; second, it is above the will of states; and third, it must be exercised in accordance with common utility (Urdánoz, 1960).

Trade relations reveal a lot about the parties involved. They imply mutual recognition of humanity, as rational and free agents, and equality - we do not trade with brutes, who lack reason, or slaves, who lack freedom. Trade also reciprocally acknowledges dominion and rights of ownership — we trade because it is wrong to take another's possession by force or without giving something of equal value in exchange. Trade cannot take place without the other party's consent (Urdánoz, 1960). Thus international trade implies the unity of the human race and helps overcome suspicion and unjust discrimination.

Trade is a human act carried out intelligently and freely. Ignorance and coercion vitiate human acts and render trade unjust. Unlike other human acts, however, trade is always social because it requires at least two parties. Hence trade becomes a channel for genuinely human relations, through which we recognize our fundamental interdependence.

Beginning with material needs, such as precious metals, trade could lead to more spiritual exchanges in knowledge, culture, and friendship. Trade enriches both materially and spiritually. To be sure, trade does not always result in just outcomes, and differences in power are often exploited. But these are consequences of the misuse of freedom and reason, not of trade itself. Trade can also be an opportunity for developing the virtues of justice and friendship.

On the basis of the right to communication and association, and passing through the right to free trade, Vitoria derives the rights to preach, to protect converts, and to constitute a Christian prince. Whereas material exchanges pursue well-being, spiritual exchanges seek the knowledge of truth above all. What is more natural to humans than the desire for truth? And what greater truth than religion? Thus Vitoria defends the right to preach, cognizant of the inalienable spiritual dimension of human beings. The right to preach contains the right to express and spread the truth, especially religious truths necessary for salvation. Because the right to preach is part of ius gentium, followers of Christian and non-Christian religions can exercise it equally. That means the preaching of Christianity in particular in the New World is accidental. This is a huge concession for Vitoria, bearing in mind that he was a Dominican, belonging to the Order of Preachers. Yet it is consistent with his belief that embracing the faith or conversion should be free, not imposed by war or other means (Vitoria, 1991: 285). 
Flowing from the right to preach are the rights to protect converts and to constitute a Christian prince. They hold for followers of other religions as well, as conditions for meaningful religious freedom. The right to constitute a Christian prince also draws from a polity's right to self-governance. In principle, even non-Christians who start out in minority could also exercise this right, once they reach a certain number. Religious belief cannot be imposed, and free exercise of religion, even of the "erroneous type," should at least be tolerated.

Justice is served by restoring rights to communication, free trade, and others, if necessary, even through war. Justice is likewise observed by honoring the laws of war, the topic of the second relection (De iure belli). Law and justice should not break down, even in war. War can be made rational, subject to rules and law. Despite the use of force and violence, war should still be carried out humanely. Although better known in the breach than in the observance, Vitoria dedicated efforts to establishing the rules of engagement for a just war of occupation in the New World.

What lessons can we draw from De iure belli for trade? Vitoria does not use war as an allegory for trade; rather, he posits the restoration of the right to free trade as one of the purposes of a just war. Its denial produces an "injury" for which parties may seek redress. The ultimate aim of a just war is the reestablishment of security and peace among communities and nations. Then trade could proceed untrammeled.

Trade, because of its voluntary and mutually beneficial nature, is the opposite of war, which results in harm and coercion. Trade seeks partners; war takes hostages and executes enemies. Trade occurs through free exchanges; war produces confiscations. Trade thrives when state intervention is minimal; war calls for widespread state control and planning. Trade should be able to go on regardless of rulers; war demands that certain rulers be deposed and others put in place. Trade builds up; war destroys. Trade is at the least tolerant of differences and at best nurturing of friendships; war divides and separates, often unleashing the worst behavior in humans. Trade and war make opposite contributions to the orbs: trade avoids marginalization and engages people in the shared quest for flourishing; war creates injustice and inequality, often failing to acknowledge human dignity in others.

Vitoria moralizes trade by positing it as a right. Trade is a voluntary human action carried out with freedom and reason and subject to ethical judgment. All human beings equally possess the right to trade by virtue of their common nature (regardless of race, culture, religion, and so forth), giving rise to reciprocal obligations. The right to free trade is rooted in a more fundamental right to communication and association, a direct consequence of the social nature of human beings. Preceding the right to trade are the rights to travel, dwell, and migrate. Trade refers not only to material objects for well-being but also to spiritual values, such as the knowledge of truth, culture, and religious beliefs. The right to trade is closely connected to the rights to preach, to protect converts, and to constitute Christian princes. Similarly, trade is moralized because its rejection by the Amerindians becomes a casus belli for the Spaniards, justifying their occupation of the New World. The right to trade is a matter of the virtue of justice. Trade likewise moralizes agents, not only by acknowledging their freedom, rationality, equality, and interdependence but also by providing opportunities to exercise justice and friendship. 


\section{THE RIGHT TO TRADE, JUSTICE, AND BUSINESS ETHICS}

How can Vitoria's understanding of the right to free trade impact business ethics?

First, it situates the right to free trade within ius gentium, which governs the universal commonwealth constituted by all human beings and polities. As an extension of natural law, ius gentium derives normative force from human nature, our embodied and constitutive freedom and rationality, and virtual consensus, not from any particular legislative human act. Against teachings of the Protestant Reformation (Luther and Calvin), Vitoria held that although human nature had been weakened by sin, it was not totally corrupted and continued to be a source of normativity (Pagden, 2017). The legitimacy of ius gentium is not founded on actual consent. It is not a man-made or positive law but a "divine" law, because God is the creator of human nature.

Vitoria's understanding of ius gentium as founded directly on natural law and indirectly on divine law foreshadows several papal declarations in Catholic social teaching. Although ius gentium is a topic for law and the philosophy of law, whereas Catholic social teaching is part of moral theology (John Paul II, 1987; Sison et al., 2016), both make universal normative claims on human actions and conduct. Rights come from God, not from any mythical prepolitical "state of nature," and supersede man-made civil laws that contradict them (such as the iniquitous laws of Nazi Germany) (Pius XI, 1937). Against racism (particularly anti-Semitism), Pius XII (1939) reminds us that all human beings have a common origin and equally share in the same rational nature. They possess the same rights (including the right to free trade and others rights contained in ius gentium) and bear reciprocal duties. Among humans, there are no slaves by nature or intrinsic constitution. Political communities, which also enjoy rights and duties, are sovereign, or capable of self-rule, and equal within the orbs, thus providing a basis for the critique of colonialism. No superior races or polities are destined to rule over others. As John XXIII (1963) affirms, "each individual man is truly a person. His is a nature, that is, endowed with intelligence and free will. As such he has rights and duties, which together flow as a direct consequence from his nature. These rights and duties are universal and inviolable, and therefore altogether inalienable." Ius gentium, therefore, provides a rational universal standard by which economic transactions and business behaviors can be morally judged, while accommodating legitimate cultural and social diversity.

Second, Vitoria's teachings provide arguments against the belief that trade is something purely mechanical or transactional, with its own laws, independent of ethics. Think, for instance, of Adam Smith's ([1776] 1981) The Wealth of Nations taken separately from his Theory of Moral Sentiments ([1759] 1982), or a cursory reading of Milton Friedman's (1970) essay on the social responsibility of business, which has led some to the idea of "amoral markets." Another variant is the assumption that trade, commerce, and economic activity in general compose just one more compartment of the several constituting social life whose rules are unique and independent of each other (MacIntyre, 1988). Trade is not a morally inconsequential game that could be bracketed but a voluntary, morally freighted human action. 
Market "laws" aren't inexorable, like laws of physics, but result from the aggregate of ethically significant human choices. Trade ought to be carried out freely and rationally; force and fraud would invalidate it. Not that all trades or trade itself is always moral, for instance, slave trading and fraudulent or exploitative exchanges are objectionable. At the outset, trade is morally neutral or ambivalent. But once certain conditions of justice are met, trade can be mutually beneficial, as originally intended. In this respect, Vitoria's ideas are several centuries ahead of the doux commerce thesis popularized by Enlightenment authors, according to which trade civilizes people, making them less prone to violent and irrational behaviors (Hirschman, 1977). As a natural lawyer, moral theologian, priest, and confessor, Vitoria's interest in trade springs from a concern over its impact on people's souls as they struggle for spiritual perfection, cultivating virtues and avoiding vices with the help of grace and the sacraments.

Third, trade is presented as an opportunity to develop the virtues of justice and friendship, among other virtues. Trade is not merely instrumental to wealth creation or the production of material goods but likewise impacts the moral standing of the parties involved. The virtue of justice is defined as the constant and firm will or habit to give to each other his or her right or due (STh II-II q. 58, a. 1) and requires three conditions: an "other" (alteritas), equality (aequalitas), and a "right" or "due" (ius). The "other" refers to the fact that justice is a social virtue, involving at least two individuals; equality, that individuals are the same in some respect, such as their humanity or as buyer or seller; and the "right" or "due," the object of exchange, because every "right" has a corresponding "duty" or "obligation." There is a species of justice, called commutative justice ( $S$ Th II-II q. 61, a. 1), that involves two individuals with regard to each other and not as parts of the whole. The right to free trade advocates nondiscrimination between partners on account of race, culture, religion, and so forth. Europeans should not trade with Europeans alone, nor Amerindians with Amerindians exclusively. Commutative justice requires strict equality between the objects of exchange. Precious metals from the New World ought to be paid for with goods of equal value for American natives. Another species, distributive justice, speaks of duties of political communities with respect to individual citizens. By virtue of distributive justice, states are enjoined to respect, protect, and, to the degree possible, guarantee the free exercise of the right to trade by its citizens, waging war, if need be. That is why the Spanish Crown is entitled to levy taxes on transatlantic commerce as payment for keeping the sea routes secure.

Similarly, trade is an occasion to grow in friendship with our "other selves," with whom we share our human nature. Through thoughtful trade, we help each other remedy material needs. We also gain a chance to experience common pleasures, fulfillments, or satisfactions. Vitoria is clear that the exercise of private dominion and ownership by individuals and public dominion by political communities do not nullify the natural law common dominion of the orbs in case of need (Añaños, 2013), equivalent to the principle of the universal destination of goods. Ideally, trade allows us to exercise benevolence, desiring the good of others even before our own. By linking trade to the social virtues of justice and friendship, its connection with human flourishing is firmly established. The ultimate rationale for free, just, and friendly 
trade then becomes the common good of human flourishing in the orbs. As a result, in due course, alongside Amerindian cities, Spanish cities, such as Puebla in Mexico, were built and established, after buying land from its original owners (Prem, 1992). Within the Catholic tradition, human rights are meant not only to protect individuals from abuse by the powerful, especially the state, but also to promote the good life within polities (Calo, 2015: 107).

Fourth, the right to free trade has significant repercussions in travel, tourism, and migration. It legitimizes an inherent desire to discover other parts of the world, our common home, and places the onus on states to provide reasons for its curtailment. Even Spanish conquerors were initially explorers of an alternative trade route to the Oriental Indies. And once they had settled in the New World, several waves of European migrations were soon to follow. Absent intent of harm, neither property rights nor territorial sovereignty is supposed to get in the way of "men's free mutual intercourse with one another" (Vitoria, 1991: 278). Without renouncing order, a necessary condition for the common good, Vitoria's position seems closer to an international open-borders policy than one restrictive of migration. He would be against the dominant position nowadays that acknowledges the rights of travel, tourism, and migration only for the rich, while denying these rights to the poor, who desperately need such opportunities the most.

Fifth, the right to free trade is supportive of religious freedom, particularly of preaching and worship or practice. Vitoria understands the rights constituting ius gentium as a whole and explains each according to its relative order of importance. Fundamental is the right to communication and human association, then the rights to travel, settle, and migrate, which make communication and association possible, somehow embodying them. Then comes the right to trade. Although initially, trade is conceived as a manner of remedying material needs, through a more rational and voluntary distribution of resources, it can also be understood as a vehicle for the spread of all sorts of knowledge and skills. Trade, therefore, extends to the free circulation of ideas, including religious ones. Otherwise, how else could humans come to know the truth, if they were not allowed to communicate with each other? Again, the only limit is harm. For instance, religious freedom would not cover ritual human sacrifices and cannibalism, and preventing such antinatural practices is a just cause for war.

Vitoria here adumbrates the Catholic teaching on religious freedom best expressed in Paul VI's (1965) Dignitatis Humanae, no. 2: a person should not be "forced to act contrary to his own beliefs, whether privately or publicly, whether alone or in association with others within due limits," and that "the right of the human person to religious freedom is to be recognized in the constitutional law whereby society is governed and thus is to become a civil right." Not only is Vitoria against forced conversions; he is also ahead of his time in advocating the distinction between religious and secular spheres, represented by the pope and the emperor. He is aware of the corrupting effects of secular leaders overstepping into the realm of the spiritual as well as the other way around. He does not go so far, however, as to propose the separation of church and state or ending state-sponsored religion, although perhaps he timidly breaks ground for this. 
Last, the anachronism notwithstanding, Vitoria could be characterized as an "economic liberal" and defender of private initiative and free markets, in opposition to mercantilist tendencies of state control and central planning. Freedom, however, should be exercised always in conformity with reason and natural law for the purpose of moral perfection. Unlike Enlightenment liberals, he thinks freedom is not absolute and self-justifying, nor is law necessarily opposed to it; freedom is a God-given gift to all, not a purely individual characteristic in a hypothetical state of nature before the social contract (Gaus, Courtland, \& Schmidtz, 2018). Vitoria believes that individual freedom in economic affairs is the path to peace and security, and ultimately to flourishing, to which all are inclined. With an eye to the common good, he strives to protect "dominion," individual rights of ownership (Dierksmeier, 2019b). Property is the necessary complement for the exercise of individual freedom. We find echoes of Vitoria's teachings on private property as a natural right and the duty to use it for the common good in Leo XIII's (1891) Rerum Novarum, nos. 913 and Pius XI's (1931) Quadragesimo Anno, no. 29, among other texts. Because individuals are masters and owners of their goods, they should be allowed to trade freely and reach agreements between themselves. In trade, whatever is not prohibited is allowed (Vitoria, 1991: 278). Trade constraints are considered punishments, requiring just cause. The burden of proof, then, lies with those who seek to impose limitations. To proceed otherwise is to commit a grave injustice.

\section{EPILOGUE: THE SIGNIFICANCE OF VITORIA'S OTHER WRITINGS FOR BUSINESS ETHICS AND A PRE-ENLIGHTENMENT THEORY OF HUMAN RIGHTS}

We began this article by introducing the historical figure and context of Francisco de Vitoria, founder of the School of Salamanca and, arguably, of modern economic science as well. We observed that very little was written about the relevance of Vitoria's teachings for business ethics compared to other members of the school and sought to fill this research gap. We centered on Vitoria's De Indis and De iure bello, which endeavored to justify Spanish presence in the New World, giving rise to ius gentium (law of the peoples). Ius gentium is an extension of natural law, from which it draws universal normativity based on human rationality and freedom. Unlike positive, civil law, ius gentium does not require any particular legislative act or promulgation, depending instead on a virtual consensus. Ius gentium is also a forerunner of international law.

Among the rights enshrined in ius gentium is the right to free trade. It derives from the basic right to communication and human society and is inextricably linked to the rights to travel, settle, and migrate. (The near-universal lockdown caused by the COVID-19 pandemic only served to show the deleterious human and economic effects of the curtailment of movement and trade.) Further rights issue from the right to free trade, such as the right to preach, to protect Christian converts, and to establish a Christian prince. For Vitoria, the denial of these rights constitutes a just cause for war on the part of Spaniards against Amerindians. 
We then focused on the significance of the right to free trade for business ethics through the virtue of justice. It is a universal right that accrues equally to all individuals and polities, accompanied by its own set of duties. The exercise of the right to trade is never ethically indifferent, nor the workings of the market (the aggregate of individual trade decisions) amoral. Instead, trade uniquely provides people and communities with opportunities to advance in material well-being (through a better, more rational distribution of resources) and to achieve spiritual growth and development (through the acquisition of knowledge, skills, and the virtues of justice and friendship, among other virtues). Trade can also be a vehicle for the spread of religion-one of humankind's highest aspirations. Vitoria can be seen as a pioneer in liberal thought, insofar as he argued that religious belief should never be imposed but only freely embraced. This tendency carries over to his politics, where he favors the distinction between religious and secular realms, and to his political economy, where he supports free markets over mercantilist policies.

What follows are areas we have identified for further research.

So far, we have studied mainly Vitoria's relections on the Spanish conquest of the New World. However, drawing on other writings, particularly his commentaries on Aquinas's Summa Theologiae, we may be able to develop more fully his ideas on business or commerce, not only as legitimate activities, but also as constituting a worthy Christian profession, open to moral perfection (Castillo Cordova \& Zorroza, 2015). Much of this relies on his theory of a "just price," the agreed price ("common estimation") between buyer and seller in the free market, absent ignorance, force, or fraud (Cendejas, 2018). Thus Vitoria opposes monopolies, monopsonies, and hoarding. Besides the cost of production, the just price also takes into account demand and supply, the subjective value or desirability of goods, the risks they entail in transport, competition, and so forth (Vitoria, 1991: 83-85). Consequently, merchants who buy goods where abundant and sell them where scarce may command a higher price for their service (Vitoria, 1991: 86). Here lies the particular expertise or virtue of merchants, in their keen speculative ability.

Second, we may also explore how ius gentium provides an alternative to the dominant Enlightenment theory of human rights. Rights in the Enlightenment are mostly understood as absolute claims or powers, guaranteed by state resources, that individuals make against others (Holmes \& Sunstein, 2000) in an adversarial, zerosum fashion. In late modernity, rights have even been accorded to members of other animal species and inanimate geographic features. Rights in ius gentium differ by being personalist (not individualist), about the common good (not material preference satisfaction), and based on the normativity of human nature (not positivistic). Ius gentium takes humans to be essentially relational and social, besides individual, and does not presuppose any "state of nature" prior to a "social contract" (Fortin, 1996b). Human beings are not themselves without others, because even their individuality is rooted in relationships, and they achieve fulfillment only in communion. Furthermore, human beings are considered fully and completely with their encumbrances and embeddedness in communities (Spaniards, Europeans, Christians, Amerindians, non-Christians, and so forth) rather than as purely abstract individuals characterized solely by rationality and freedom. In ius gentium, subjective rights not 
only seek the fulfillment of individual material desires but also pursue (perhaps even more) shared or common goods. Moreover, these goods are considered perfective of human nature rather than mere expressions of absolute individual preferences. As a basis for international law, ius gentium propounds a notion of political sovereignty not as freedom from interference but as autonomy in decision-making limited by natural law and the common good of the orbs (Castilla Urbano, 2017; Langella, 2017). Individuals are also granted legal standing, unlike in modern international law, which only recognizes states.

Third, future investigators could show how Vitoria's teachings on the ius gentium may serve as inspiration for Catholic social tradition in engaging with contemporary human rights discourse dominant in the regulation of business and the economy (Calo, 2015; Shupack, 1999). Vitoria upholds the principles of human dignity, the common good, the universal destination of goods, private property, subsidiarity, and solidarity (Alves, 2017). More importantly, ius gentium is completely compatible with virtue ethics and the natural law tradition, unlike the Enlightenment version of human rights (Benestad, 1996; Craycraft, 1995; Fortin, 1996a; Lockwood O’Donovan, 1997; MacIntyre, 1983). Vitoria's writings, then, can help bridge the gap between a human rights approach, which establishes minimum acceptable conditions of behavior; virtue ethics, which points toward excellence and communal flourishing; and Catholic social teaching.

Fourth, researchers could explore how Vitoria, leader of the Late Scholastics of Salamanca, is indeed a precursor of liberal, cosmopolitan, and free market ideas in "scientific economics" often attributed to Adam Smith and other Enlightenment authors (Grice-Hutchinson, 1952, 1975). It would be interesting to note as well how Vitoria differs from these later thinkers.

And last, Vitoria offers a new perspective from which to regulate the challenges of globalization, not only in terms of travel, trade, and migration (for instance, against China's claim of exclusive dominion over the South China Sea, the site of major trade routes), but also in issues pertaining to multiculturalism, on the level of individuals, states, and multilateral nonstate actors. Ius gentium originated precisely to govern relationships between two individuals who perhaps have nothing in common besides human nature, very similar to contemporary globalization scenarios. Of particular interest are the ethical and legal issues posed by the internet and digital technologies, which lead to unprecedented interdependence among nations and peoples through the free circulation of information, norms, ideas, and values (Vallor, 2016). The internet is like the waterways of old, through which peoples were able to travel and communicate with each other, hence the importance of guaranteeing access to everyone. The right to communication and human society provides normative orientation for the use of social media and digital commons in the fully wired, panoptic world.

\section{REFERENCES}

Alves, A. A. 2017. Vitoria, the common good, and the limits of political power. In J. M. Beneyto \& J. Corti Varela (Eds.), At the origins of modernity: Francisco de Vitoria and the discovery of international law: 63-75. Cham, Switzerland: Springer. 
Alves, A. A., \& Moreira, J. M. 2013. The Salamanca school. New York: Bloomsbury.

Añaños Meza, M. C. 2013. La doctrina de los bienes comunes de Francisco de Vitoria como fundamentación del dominio en el Nuevo Mundo. Persona y Derecho, 68: 103-37.

Aquinas, T. 2006. Summa theologiae (English Province of the Order of Preachers, Ed.). Cambridge: Cambridge University Press.

Araujo, J. 2012. Our debt to de Vitoria. Ave Maria Law Review, 10(2): 313-29.

Barcia Trelles, C. 1928. Francisco de Vitoria, fundador del Derecho Internacional moderno. Valladolid, Spain: Universidad de Valladolid.

Benestad, J. B. 1996. Foreword. In J. B. Benestad (Ed.), Human rights, virtue, and the common good: Untimely meditations on religion and politics: xii-xiii. Lanham, MD: Rowan and Littlefield.

Calo, Z. R. 2015. Catholic social thought and human rights. American Journal of Economics and Sociology, 74(1): 93-112.

Castilla Urbano, F. 2017. Prevention and intervention in Francisco de Vitoria's theory of the just war. In J. M. Beneyto \& J. Corti Varela (Eds.), At the origins of modernity: Francisco de Vitoria and the discovery of international law: 141-53. Cham, Switzerland: Springer.

Castillo Cordova, G., \& Zorroza, I. 2015. Actividad económica y acción moral: una revisión del supuesto antropológico moderno en la descripción del mercado de Francisco de Vitoria. Revista Empresa y Humanismo, 19(1): 65-92.

Cendejas Bueno, J. L. 2018. Justicia, mercado y precio en Francisco de Vitoria. Revista Empresa y Humanismo, 21(1): 9-38.

Craycraft, K. 1995. Religion as moral duty and civic right: Dignitatis Humanae on religious liberty. In G. B. Kenneth Grasso \& R. Hunt (Eds.), Catholicism, liberalism, and communitarianism: The Catholic intellectual tradition and the moral foundation of democracy: 59-80. Lanham, MD: Rowman and Littlefield.

Cruz Prados, A. 1991. Para un concepto de "guerra" de una filosofía de "paz": actualidad del pensamiento de Vitoria. Anuario de Filosofía del Derecho, 8: 103-40.

Dierksmeier, C. 2019a. From Jensen to Jensen: Mechanistic management education or humanistic management learning? Journal of Business Ethics. DOI: 10.1007/ s10551-019-04120-z.

Dierksmeier, C. 2019b. Globalization ethics in the 16th century? Why we should re-read Francisco de Vitoria. In D. T. Orique \& R. Roldan-Figueroa (Eds.), Bartolome de las Casas, OP: History, philosophy, and theology in the age of European expansion: 197-217. Leiden, Netherlands: Brill.

Duve, T. 2020. The School of Salamanca: A case of global knowledge production. In T. Duve, C. Birr, \& J. L. Egío García (Eds.), The School of Salamanca: A case of global knowledge production? (Max Planck Institute for European Legal History Research Paper Series 2020-12): 5-37. Leiden, Netherlands: Brill.

Fassó, G. 1982. Historia de la filosofía del derecho, la edad moderna. Madrid: Pirámide.

Fernández Ruiz-Gálvez, E. 2017. El totus orbis y el ius gentium en Francisco de Vitoria: el equilibrio entre tradición e innovación. Cuadernos Electrónicos de Filosofía del Derecho, 35: 19-44.

Fortin, E. 1996a. Human rights and the common good. In J. B. Benestad (Ed.), Human rights, virtue, and the common good: Untimely meditations on religion and politics (Ernest L. Fortin: Collected Essays, vol. 3): 1-10. Lanham, MD: Rowan and Littlefield.

Fortin, E. 1996b. Natural law. In J. B. Benestad (Ed.), Human rights, virtue, and the common good: Untimely meditations on religion and politics (collected essays, vol. 3): 5-12. Lanham, MD: Rowan and Littlefield. 
Friedman, M. 1970. The social responsibility of business is to increase its profits. New York Times Magazine, September 13.

Gaius. 1925. Gai institutiones; or, Institutes of Roman law by Gaius. London: Oxford University Press.

Gascón y Marín, J. 1932-33. Vitoria y el Derecho Público. In Anuario de la Asociación Francisco de Vitoria, vol. 10: 13-42. Madrid: Consejo Superior de Investigaciones Científicas, Instituto Francisco de Vitoria.

Gaus, G., Courtland, S. D., \& Schmidtz, D. 2018. Liberalism. In E. N. Zalta (Ed.), Stanford encyclopedia of philosophy (Spring 2018 ed.). https://plato.stanford.edu/archives/ spr2018/entries/liberalism/.

Grice-Hutchinson, M. 1952. The School of Salamanca. Oxford: Clarendon Press.

Grice-Hutchinson, M. 1975. Early economic thought in Spain 1177-1740. London: Allen and Unwin.

Hirschman, A. 1977. The passions and the interests: Political arguments for capitalism before its triumph. Princeton, NJ: Princeton University Press.

Holmes, S., \& Sunstein, C. 2000. The cost of rights. New York: W. W. Norton.

Isidore of Sevilla, S. 1983. Etymologies. Paris: Les Belles Lettres.

John XXIII. 1963. Pacem in terris, no. 9.

John Paul II. 1987. Sollicitudo rei socialis, no. 41.

Langella, S. 2017. The sovereignty of law in the works of Francisco de Vitoria. In J. M. Beneyto \& J. Corti Varela (Eds.), At the origins of modernity: Francisco de Vitoria and the discovery of international law: 45-61. Cham, Switzerland: Springer.

Leo XIII. 1891. Rerum novarum, nos. 9-13.

Lockwood O'Donovan, J. 1997. The concept of rights in Christian moral discourse. In M. Cromartie (Ed.), A preserving grace: Protestants, Catholics, and natural law: 143-56. Grand Rapids, MI: Eerdmans.

MacIntyre, A. 1983. Are there any natural rights? Brunswick, ME: Bowdoin College.

MacIntyre, A. 1988. Whose justice? Which rationality? Notre Dame, IN: University of Notre Dame Press.

Melé, D. 1999. Early business ethics in Spain: The Salamanca school (1526-1614). Journal of Business Ethics, 22: 175-89.

Menéndez Reigada, I. G. 1931-32. El Derecho de gentes según el P. Vitoria. In Anuario de la Asociación Francisco de Vitoria, vol. 9: 46-61. Madrid: Consejo Superior de Investigaciones Científicas, Instituto Francisco de Vitoria.

Muñoz de Juana, R. 2001. Scholastic morality and the birth of economics: The thought of Martín de Azpilicueta. Journal of Markets and Morality, 4(1): 14-42.

Pagden, A. 2017. Francisco de Vitoria and the origins of the modern global order. In J. M. Beneyto \& J. Corti Varela (Eds.), At the origins of modernity: Francisco de Vitoria and the discovery of international law: 1-17. Cham, Switzerland: Springer.

Paul VI. 1965. Dignitatis humanae, no. 2.

Pius XI. 1931. Quadragesimo anno, no. 29.

Pius XI. 1937. Mit brennender sorge, no. 30.

Pius XII. 1939. Summi pontificatus, no. 29.

Prem, H. J. 1992. The Americas before and after 1492: Current geographical research. Annals of the Association of American Geographers, 82(3): 444-59.

Salas, V. M. 2012. Francisco de Vitoria on the ius gentium and the American indios. Ave Maria Law Review, 10(2): 331-41.

Sarmiento, A. 2009. La obligatoriedad de las leyes civiles según Francisco de Vitoria. Scripta Theologica, 41(2): 585-610. 
Schumpeter, J. A. 1954. History of economic analysis. New York: Oxford University Press. Scott, J. B. 1934. The Spanish origin of international law: Francisco de Vitoria and his law of nations. New York: Oxford University Press.

Shupack, M. 1999. The Church and human rights: Catholic and Protestant human rights views as reflected in Church statements. Harvard Human Rights Journal, 6: 127-57.

Sison, A. J. G., Ferrero, I., \& Guitián, G. 2016. Human dignity and the dignity of work: Insights from Catholic social teaching. Business Ethics Quarterly, 26(4): 503-28.

Smith, A. (1759) 1982. The theory of moral sentiments (D. D. Raphael \& A. L. Mcfie, Eds.). Indianapolis, IN: Liberty Fund.

Smith, A. (1776) 1981. An inquiry into the nature and causes of the wealth of nations $(\mathrm{H}$. Campbell \& A. S. Skinner, Eds.). Indianapolis, IN: Liberty Fund.

Tierney, B. 1997. The idea of natural rights: Studies on natural rights, natural law, and Church law 11501625 (Emory University Studies in Law and Religion). Atlanta, GA: Emory University.

Truyol y Serra, A. 1977. La sociedad internacional. Madrid: Alianza.

Urdánoz, T. 1960. Obras de Francisco de Vitoria: relecciones teológicas. Madrid: BAC.

Urdánoz, T. 1967. La sociabilidad natural y solidaridad humana universal. In L. Pereña Vicente \& J. M. Pérez Prendes (Eds.), Relectio de Indis o libertad de los indios: 27-52. Madrid: Consejo Superior de Investigaciones Científicas, Instituto Francisco de Vitoria.

Vallor, S. 2016. Technology and the virtues: A philosophical guide to a future worth wanting. New York: Oxford University Press.

Viola, F. 2004. Derecho de gentes antiguo y contemporáneo. Persona y Derecho, 51: 16589.

Vitoria, F. de. (1535) 2001. La justicia. Madrid: Técnos.

Vitoria, F. de. (1539) 1981. Relectio de iure belli o paz dinámica (L. Pereña, Ed.). Madrid: Consejo Superior de Investigaciones Científicas, Instituto Francisco de Vitoria.

Vitoria, F. de. 1991. Vitoria-political writings (A. Pagden \& J. Lawrence, Eds.). Cambridge: Cambridge University Press.

Wren, D. A. 2000. Medieval or modern? A scholastic's view of business ethics, circa 1430. Journal of Business Ethics, 28(2): 109-19.

Alejo José G. Sison is professor at the School of Economics and Business of the University of Navarra. His research deals with the issues at the juncture of ethics with economics and politics, with a focus on the virtues and the common good. He is section editor for "Philosophy and Business Ethics" at the Journal of Business Ethics and a member of the editorial board of Business Ethics Quarterly.

Dulce M. Redín (dredin@unav.es, corresponding author) is professor at the School of Economics and Business of the University of Navarra. Her research has focused on virtue ethics in business and management. She has published her research in journals such as the Journal of Business Ethics and Business Ethics: A European Review.

This is an Open Access article, distributed under the terms of the Creative Commons Attribution licence (http://creativecommons.org/licenses/by/4.0/), which permits unrestricted re-use, distribution, and reproduction in any medium, provided the original work is properly cited. 